\title{
Impoverishment Against Corruptors
}

\author{
I Nyoman Sujana, I Nyoman Gede Sugiartha \\ Faculty of Law \\ Universitas Warmadewa \\ Denpasar-Bali, Indonesia \\ nyomansujana@warmadewa.ac.id
}

\begin{abstract}
This paper is inspired by circumstances where the level of corruption is increasing both in quantity and quality. Corruption is increasingly massive and widespread not only by executive, legislative but also law enforcement officials. Criminal sanctions imposed on corruptors are not optimal and are not affection to a deterrent effect, so it is considered unfair by the public. Therefore, a new penal law perspective is necessary, which is more likely to be in the form of impoverishment sanctions against corruptors. In Indonesia, within the positive criminal law, there is no provision of impoverishment against corruptors, thus there is a void of norms. We used normative juridical perspective comprising statute approach and conceptual approach to legislation with law enforcement and justice theories to examine two issues covering the urgency of impoverishment against corruptors and the legal arrangement of impoverishment against future corruptors in corruption eradication. The results showed that impoverishment sanctions against corruptors are urgently needed for the redemption of state finances looted by corruptors for the welfare of the people.
\end{abstract}

Keywords-corruption crime; law enforcement;

\section{INTRODUCTION}

The 2003 United Nations Convention Against Corruption Convention has been ratified by the Indonesian government through Law No.7 of 2006 on Ratification of UNCAC [1]. This means that corruption is not only a national but Regional and International issue. The UNCAC regulates five important aspects of corruption prevention, investigation and prosecution of corruption cases, freezing of corruption assets, seizure of corruption assets, and the return of corrupt assets.

Based on the provisions in the Law no. 7 of 2006, legal efforts to return the assets of corruption is then adopted [1]. In the framework of Eradication of Corruption in Indonesia include criminal sanctions in the form of criminal substitute for state financial losses equal to the money of corruption. In addition, the Corruption Law also threatens criminal penalties as stipulated in the 31 no. 31 of 1999 of the Law [2]. From the set of rules above, clearly there is a state's legal policy to be able to assets state assets including state finances that have been illegally looted in the form of corruption. Thus efforts to restore state assets and finances are made to the maximum extent possible to return intactly to the state for the welfare of society.
Various jurisprudence shows that so far the court's decision on corruption cases has not fulfilled the public sense of justice, has not caused a deterrent effect for the perpetrators, and not infrequently the result of corruption has been used to commit other criminal act of money laundering which is predicating crime is corruption.

In relation to the above matters, international punishment is required to provide impoverishment on corruptors to make the corruptors become powerless, economically weak; through the law enforcement, the state finances can be returned to the state for the sake of the welfare of society.

As an extraordinary crime,corruption is an act of violating ethical, moral, religious and legal values that it has developed massively and deeply because of it is as cancer has damaged all elements of the power of both the executive, legislative and even law enforcement officers.

The nation is treated to an incessant daily corruption story, including the Operation of Hand Capture (OTT) of public officials such as Regents/Mayors/Governors/Ministers/High Officials in various departments, members of Parliament even law enforcement officers. Collaboration between the ruler and the entrepreneur is one of the causing factors for the corruption criminal act to be increasingly endemic in Indonesia such as E.KTP Case, BLBI, there is Hambalang case.

That is why the Corruption Perception Index in Indonesia has not progressed significantly since the CPI is ranked 132 out of 177 countries, Indonesia over Vietnam, Cambodia under Malaysia and Singapore. It has a serious impact on people's lives, depriving people of economic and social rights, detrimental to the state's finances and economies, which hamper the investment climate, even the disruption of the nation's development process. The act against the law must be dealt with firmly so that the state's finances and economy are not looted for the benefit of other people's corruptors, as well as corporations, but action must be taken by the state through various legal efforts include impoverishment of corruptors.

The judge's verdict in the form of a life sentence against Akil Mochtar is expected to be a moral message of law enforcement in Indonesia as well as a preventive function. The judges' ruling incised a new history because it was the first time that the Criminal Corruption Court (Tipikor) had imposed a life-long penalty since the establishment of a corruption court. 
The essence of impoverishment of corruptors is expected to affect families, citizens not to commit corruption, because the impoverishment of corruptors makes the perpetrators powerless economically and tarnished the ethical, moral, propriety and ethical values of society. These points encourage authors to review and analyze impoverishment against corruptors. This study aims to see the urgency of impoverishment of corruptors in the eradication of criminal acts of corruption and how to set impoverishment against future corruptors.

\section{LITERATURE REVIEW}

Etymologically, the word corruption comes from the Latin corrumpere, known known as 'corruption' (English), corruptie (Netherlands). It is from Dutch that the word is derived from Indonesian to corruption [3]. Furthermore, Hamzah stated the term 'corruption' in the Indonesian, namely "korupsi, penyuapan, immoralitas, and ketidakjujuran" [3].

In addition, the word corruption is also used to designate a state or act of decay. Corruption is often linked to one's financial dishonesty [4]

When viewed from historical perspective in Indonesia there had been a number of legislation regarding eradication of corruption, namely:

- Military Regulation at the time of military emergency (Military Rule Regulation No. 06/PM/1957, Military Rule No. 013/PM/1958)

- Government Regulation in Lieu of Law N0. 24 of 1960 based on the Law no. 1 of 1961 amanded to Law no. 24/Prp/1960 concerning Investigation, Prosecution and Corruption Criminal Investigation.

- Law No. 3/1971 on Corruption Eradication is valid for almost three decades.

- Law no. 31 of 1999 amended to Law No. 20 Year 2001 on the Eradication of Corruption.

Similarly, there are several related legislation on Corruption Eradication namely:

- Law no. 28 of 1999 on the Government of a Clean Country and Free from the practice of Corruption, and Nepotism [5].

- Law no. 30 of 2002 on the Corruption Eradication Commission [6].

- Law No. 7 of 2006, adopted on 18 April 2006 on the ratification of the United Nations Convention against Corruption, 2003 (United Nations Convention against Anti-Corruption 2003).

- Law no. 5 of 2009 [7] on the Ratification of the United Nations Convention Against Transnational Organized Crime and several technical regulations such as Presidential Instruction No. RI. 5 Year 2004 [8] on the Acceleration of Corruption Eradication.

In the era of reformation, eradication corruption criminal acts had a very important momentum since it became the main agenda with the stipulation of People's Consultative Assembly
(MPR) XI No. XI Year 1998 which obliges the government to eradicate corruption, collusion and nepotism. The MPR's decision resulted passage of 31 of 31 no. 31 Year 1999 on August 16, 1999. This law was adopted following the 8th UN Congress of 1990 under the heading "Recommendations on international co-operation for crime prevention and criminal justice in the context of development states as follows:

Because corruption activities of public officials can destroy the potential effectiveness of all types of government programs, disrupt/impede development, and cause individual victims and community groups [9].

Through the formation of reforms aimed at the rule of law and also the encouragement of the UN, it is expected that this law will function properly.

With the existance of Law no. 31 of 1999 replacing Law no. 3 of 1971, it is expected to fulfill the sense of community justice in eradicating corruption and anticipate the development of society in order to prevent and eradicate more effective against corruption crime which is very detrimental to state finance and state economy.

Law No.31 of 1999 was born in accordance with the increasing demands of society to eradicate corruption. This law according to Hadi Setia Tunggal contains several new substances [10]:

- Corporations as subjects of corruption can be subject to sanctions, because corporations in various forms increasingly play a role in modern life.

- Adaya Balanced Proof that defendant is obliged to give information about all his property and property of wife or husband, children and property of every person who has relationship with the case concerned.

- The existence of minimum penalty and death penalty. This is to avoid punishment disparities that often occur.

- The existence of imprisonment for the perpetrators of corruption which can not pay additional crime in the form of state compensation money.

- This law provides the widest possible space for the public to participate in preventing and eradicating criminal acts of corruption.

- Establishment of joint team consisting of Polri and Attorney General Office to handle corruption which is difficult to prove.

- The idea of establishing a Corruption Eradication Commission (KPK). This law mandates that the establishment of KPK institutions can be done no later than two years.

Corrupt impoverishment is a natural act because of it is like opium, which keeps the culprit addicted to stealing people's rights and it can destroy the life of a nation. Therefore, such crimes must be terminated for the welfare of society [11]

This is related to the perpetrators of criminal acts of corruption is not the poor but is a public official with a fairly 
high education with a relationship and authority both in government and private sector.

\section{RESEARCH METHOD}

This research uses normative juridical research method. The normative juridical method is also referred to as doctrinal research, a study which refers to legal analysis in the legal sense as written by judges through the judiciel process [12]

Soekanto argues that in law science, there are two types of legal research namely normative legal research and sociological or empirical legal research [13]. Normative legal research is legal doctrinal research and library legal research. It is referred to as a doctrinal legal research because the research is conducted on written rules, or other legal materials, while the so-called literature research is a study conducted on the sources of document-based literature, and this literature study method is used because the dominant analysis is performed on data sources secondary obtained from the library [14].

The approach used in this study is the legal approach and legal doctrine. In this case, the authors explore the views of jurists to find relevant legal concepts and principles. Meanwhile, the source of legal material is obtained from material sources containing authoritative legal issues written with legal authority in the form of publications but not legal documents relating to impoverishment of corruptors, legal papers, scientific opinions and others related to corruption. The technique of collecting legal materials is done by card system. In this card system, literature review is done by recording and understanding the primary and secondary legal materials related to impoverishment of corruptors. Data analysis is done by descriptive method including explaining, describing and giving analysis to existing law material form of law which regulate implication of impunity to corruptor, and then interpretive analysis done by giving explanation about each law which rules impoverishment of corruptor.

\section{RESULT AND DISCUSSION}

Discussion of the term "impoverishment" of corruptors is an important issue in society because the wealth and finances of the country that have been plundered by corruptors must be returned to the state. Impoverishment is inseparable to the meaning of poverty, a condition in which people cannot meet their living needs, while impoverishment is a process whereby people become poor. Many things that cause the poor, among others can be due to corruption.

In the positive law, there is no provision of impunity penalties against corruptors resulting in a void of norms. Although the term impoverishment is not recognized in the law, there are, however, several articles concerning the provisions of criminal sanctions that can be qualified as impoverishment of corruption if the threat of criminal sanctions is applied seriously. In Article 10 letter b. The additional criminal penalty that may be imposed consists of the revocation of certain rights, the deprivation of tangible mobile goods, used for committing a crime, the payment of the surrogate, the entire payment, part of the enterprise.
The provision of Article 10 letter $b$ of the Criminal Code indicates the absence of the use of administrative sanctions and civil sanctions, including impoverishment of corruptors. The precedence is the criminal sanction so that the function of the criminal law so that the ultimum remedium principles undergo a shift to a premium remedium. Similarly, in Article 18 paragraph 1 of the Law N0 31 of 1999 as amended by Law no. 20 of 2001 which determined that additional criminal as referred to in the Criminal Code, is deprivation of tangible or intangible goods used for or derived from a criminal offense.

It is a legal fact that the imposition of criminal sanctions against corruptors so far has not resulted in a deterrent effect for the perpetrators of corruption, even the result of corruption is used to commit another larger crime in the form of moneylaundering crimes (Criminal Act of Money Laundering) corruption, as well as the case Gayus Tambunan, Akil Mochtar, Nasaruddin and others whose corruption results are used to commit Criminal Acts of Money Laundering. Therefore, the authors argue that the sanction of impoverishment of the perpetrators of corrupt acts must be made and applied so that the corruptors feel deterrent due to both economically and financially they are helpless, so that the act of corruption in the future does not continue. Given the corruption is an extraordinary crime, then the prevention of criminal acts of corruption must also be done in extraordinary ways as well. Related to that Satijpto Rahardjo said that law enforcement against corruption should not be done conventionally but through progressive law enforcement.

From the perspective above, the act of impoverishment of corruptors in the future is very important to be applied as ius constituemdum. Hence, the impoverishment of corruptors needs to be formulated since a legal norm of positive criminal law in Indonesia has not been regulated. In addition, the defendant in a corruption case is often handed down directly by the Court in order to be lighter than the Public Prosecutor's charges but has a deterrent effect on corruptors, and ultimately draws strong criticism from the public. The public's expectation on the judge's decision is that the decision given should be able to fulfill the public sense of justice so that state assets and state finances embezzled in corruption can be immediately returned to the state for the sake of the people's welfare.

Lack of law enforcement and inconsistency in decisionmaking by authorities in the practice of eradicating corruption has led to the crime that the state's financial plundering takes place on an ongoing basis. For sixteen years the Corruption Eradication Commission (KPK) has stood up and arrested many corruptors, but corruption has spread from the center of government to the bureaucracy in the region.

Only a few days passed when the Governor of Jambi ZZ was declared a corruption suspect by the KPK, it was reported that the Regent of Jombang NWS on 4 February 2018 followed to be named as a suspect over a corruption case. In the evidence of this crime, there are countless dozens of corrupt officials in the ranks of Governor/Regent/Mayor, bureaucratic officials, members of DPR, Provincial, District/City, Corporations, and law enforcement. The involvement of 
officials in the executive and judicial sectors has led to the protection of corruption cases.

news coverage in the print, electronic, social media has been adorned with daily corruption reporting without end due to the rising of financial and economic losses of the country. Faculty of Economics and Business of Gajah Mada University (FEB UGM) in 2015 once wrote that the state financial losses due to corruption reached 203 trillion rupiahs and it was only 159 trillion rupiahs returned to the state. Such a result of investigation by FEB UGM is like an iceberg, because as a result of the increasingly sophisticated modus operandi performed by corruptors. Thus, it can be assumed that there are still many cases of corruption that have not been revealed on the surface, especially every time corruption is surfaced in the media.

In the Law no. 31 Year 1999, it is affirmed that corruption is increasingly widespread, massive with some increasingly sophisticated modus operandi, especially with the advances in the field of communications and telecommunication information today [2].

Law enforcement against corruption has indeed been done but is considered not to meet the sense of community justice, has not caused a deterrent effect, even the result of corruption is used to commit other crimes such as Money-Laundering Crime. This is caused by several factors: the weakness of the prosecutor's demand, apparently the judge's verdict on corruption, the disparity of the judge's decision due to the criminal application is shorter than the maximum criminal as stipulated in Law no. 31 Year 1999 [2].

Prior to criminal sanctions, and administrative sanctions, there has been a shift in ultimum rimedium to premium rimedium.

Placing imprisonment ahead of civil and administrative sanction results in the fact that the money from corruption is subordinated to its return to the state. It also causes the hot money of corruption to be used again to commit another crime that is even greater. are:

In terms of criminal prison, there are various weaknesses

- The negative consequences of deprivation of sexual liberty, deprivation of freedom of expression, can give a stigma that will carry over, even though the person is no longer doing it.

- Degradation/degeneration of human dignity.

- Household is a crime college.

- It will produce more criminals than preventing them [15].

Moreover, from an economic perspective, Robert Cooter says: prison sentence is the most inefficient criminal form because it requires a very high social cost of impre cionment $[16,17]$

Conversely, the penalty of fines by Steven Shavell is seen as a form of financial sanction (monetary sanction) is the most efficient criminal because its imposition does not cost anything $[17,18]$

Based on the theories mentioned above, it can be analyzed, that in the criminal act of corruption, in general the criminal sanction imposed by the judge to the perpetrator of corruption is a criminal penalty and / or criminal penalty by cumulative.

In the act of corruption, in addition to being punished by imprisonment and / or a fine, the defendant may also be sentenced to an additional penalty in the form of a replacement payment of the amount equal to the amount of property derived from the proceeds of corruption. Thus according to Law no. 31 of 1999 on the Eradication of Corruption, against the defendant who has been guilty of corruption, the person may be sentenced to imprisonment, the crime of repayment and the fine.

The availability of criminal types in the anti-corruption law is not directly proportional to the reduction of corruption as the authors describe in advance. Therefore, impoverishment of corruptors becomes an alternative criminal sanction in eradicating corrupt crime.

Impoverishment of corruptors, according to the authors, in addition to causing financially/economically powerless prisoners will also benefit, as follows:

- Can be used means of prevention, both special and special prevention against corruption, as well as general prevention of society, because it will be made powerless financially/economically by law enforcers.

- Impoverishment of corruptors is more human compared to imprisonment with all the imprisonment imprisonment.

- Money from corruption can not be used to commit predicate crime such as Money Laundering Crime.

- Impoverishment of corruptors is more efficient.

- State financial losses can be recovered faster.

- More use of non penal approach (outside of criminal law) than penal (criminal law).

Given the impoverishment of corruptors not set in positive criminal law, then according to the author in the future it could serve as one additional criminal in the anti-corruption legislation.

\section{CONCLUSION}

Sanctions against corruptors in positive criminal law in Indonesia are more criminal than civil and administrative sanctions. In practice, however, sanctions pidanalah are put forward in the eradication of corruption (premium remidium).

The absence of regulation on impoverishment of corruptors in positive law means that there is a void of norms it involves penal sanctions against corruptors. It is also one of the factors causing the return of state assets and corrupted state finances can not be fully returned to the state, causing financial losses to the state and the economy of the country. It will disrupt the process of building a nation. 


\section{ACKNOWLEDGEMENT}

The author would like to thank all the parties who have helped and contributed in the writing of this article, both those who contribute in the form of funding and critical ideas. Hopefully this paper can be useful theoretically and practically for the addition and development of knowledge, especially in the field of legal science.

\section{REFERENCES}

[1] Law No.7 of 2006, passed on 18 April 2006 on the ratification of the United Nations Convention against Corruption, 2003 (United Nations Convention Against Corruption 2003).

[2] Law No.31 Year 1999 on the Eradication of Corruption as amended by Act No.20 of 2001

[3] Hamzah, A., Pengantar Hukum Acara Pidana Indonesia. Ghalia Indonesia, 1984

[4] Sudarto, 1977, Law and Criminal Law, Bandung Alumni.

[5] Law No.28 of 1999 on State Owners who are clean, authoritative, free of corruption, collusion and nepotism.

[6] Law No.30 of 2002 on Corruption Eradication Commission (KPK)
[7] Law no. 5 of 2009 on the Ratification of the United Nations Convention Against Transnational Organized Crime (United Nations Convention Against Transnational Organized Crime)

[8] Presidential Instruction No. RI. 5 Year 2004 on the Acceleration of Corruption Eradication

[9] B. N. Arief, Masalah Penegakan Hukum dan Kebijakan Penanggulangan Kejahatan. Citra Aditya Bakti. 2001

[10] H. S. Tunggal, Corruption Eradication Act and Its Implementation Act, Issuer, Harvarindo. 2000.

[11] Mertha, I. K., Corruption Impoverishment Effect of Corruptor and Criminal Sanctions, Publisher: Udayana University Press, First Print. 2014.

[12] D. Ronald, Criminalization of Money Laundering (Money Laundering), Post Graduate Program Faculty of Law University of Indonesia, Jakarta. 1973

[13] S. Soekanto, Legal Research, UI Press, Jakarta. 1986.

[14] W. Bambang, Legal Research in Practice, SinarGrafika, Jakarta. 1991.

[15] B. N. Arief, Legislative Policy In Countering Crime With Prison Crime, Publisher: Diponogoro University, Semarang. 1994.

[16] R. Coeter, Law and economics, third edition, Addison-Wesley United States. 2000.

[17] M. Ali, Principles, Theory, Practice of Corruption Criminal Law, UI Press, Yogyakarta. 2013.

[18] S. Shavell, Criminal law and the Optimal use of Non-monetory Sanetion As Detterence, Columbia Law Review. 1985. 